\title{
Roughness of the nuclear reactor pipe inner surface depending on the reactor operating time*
}

\author{
Maksim A. Trofimov ${ }^{1}$, Ruslan A. Globa ${ }^{1}$ \\ 1 Obninsk Institute for Nuclear Power Engineering, NRNU MEPhI, 1 Studgorodok, Obninsk, Kaluga Reg., 249040, Russia \\ Corresponding author: Maksim A.Trofimov (trofimovma@mail.ru)
}

Academic editor: Georgy Tikhomirov • Received 15 July 2019 • Accepted 05 September 2019 • Published 10 December 2019

Citation: Trofimov MA, Globa RA (2019) Roughness of the nuclear reactor pipe inner surface depending on the reactor operating time. Nuclear Energy and Technology 5(4): 313-316. https://doi.org/10.3897/nucet.5.48394

\begin{abstract}
During operation of nuclear reactors, there are various factors that affect the nuclear plant piping leading to erosion of the pipe inner surface and an increase of its micro-relief (roughness). Metal corrosion occurs and spreads faster on a surface having a higher value of the roughness parameter. Failure through erosive wear of the parent metal takes place predominantly in the pipe bend area. The roughness of the pipe inner surface has a sizeable effect on the signal attenuation in the process of the pipe wall ultrasonic testing. Defective main pipeline segments were cut out during preventive repairs from which samples with different operating times were taken. Five defective pipe segments of the austenitic 12Kh18N10T grade steel cut out of a high-pressure reheater's piping and five defective pipe segments of the perlite-class steel of grade 20, after different operating times, were used to determine experimentally the actual value of the pipe inner surface roughness. Besides, a piece of a new $\varnothing 273 \times 12$ pipe of the $12 \mathrm{Kh} 18 \mathrm{~N} 10 \mathrm{~T}$ steel and a piece of a $\varnothing 159 \times 6$ pipe of grade 20 steel were cut out. The inner surface roughness was measured for different segments. Dependences of the roughness value on the operating time and the pipe segment type have been obtained. Company specimens were fabricated with the inner surfaces having the roughness corresponding to various pipe operating times. This made it possible to take into account the influence of the inner surface roughness on the signal attenuation in the process of the weld integrity ultrasonic testing and during ultrasonic measurements of the weld adjacent zone grain size value following the weld repair.
\end{abstract}

\section{Keywords}

Life extension, surface roughness, metal corrosion, operating conditions, Elcometer 7061 Marsurf PS1 roughness meter, parent metal, preventive maintenance

\section{Introduction}

Since the mid-1990s, the Russian nuclear power plant operator, jointly with supporting enterprises, has been involved in the efforts to extend the service life of its NPPs considered, in recent years, in the context of a more extensive challenge of the unit life management.
The NPP pipe seam repair requires follow-up flaw inspection and the parent metal grain size control in the weld adjacent zone. Irregularities in the welding process (welding current or welding time increase) lead to a greater grain size, this causing the pipe wall metal strength to decrease and intergranular corrosion to occur which provokes the weld adjacent zone cracking and crack propagation.

* Russian text published: Izvestiya vuzov. Yadernaya Energetika (ISSN 0204-3327), 2019, n. 3, pp. 88-95. 
The key ultrasonic grain size measuring technique for the weld adjacent zone parent metal is to measure the signal (amplitude) attenuation which depends to a great extent on the pipe wall surface quality. Whereas the wall outer surface parameters can be either measured or changed in the treatment process, the inner surface is normally inaccessible. Therefore, measurement of the inner surface roughness is the major source of errors in measuring the weld adjacent zone metal grain size. The surface with a higher roughness parameter also tends to develop metal corrosion which spreads faster (Trofimov and Globa 2012, 2014, 2015). One example is a failure of the turbine plant steam line, a high-pressure reheater's piping, etc. The predicted change in the inner surface microrelief over the pipe operating time can be further taken into account in ultrasonic testing.

The purpose of the study is to acquire information on the influence of the NPP pipe operating time on the inner surface roughness. The acquired data can be further used to determine the influence of this parameter on the NPP pipe metal ultrasonic test result for the NPP life extension and for the fabrication of specimens with the estimated roughness parameter.

\section{Investigation results}

Surface roughness is a combination of the surface irregularities with relatively small pitches identified using the gage length. The surface microrelief is shown schematically in Fig. 1 (GOST 2789-73 2019).

Key: $l$-gage length; $m$ - profile centerline; $S_{m}$ - mean profile roughness pitch; $S$ - mean local peak pitch; $H_{i \text { max }}$ - deviations of the five largest profile maximums; $H_{i \min }$ - deviations of the five largest profile minimums; $h_{i \text { max }}-$ distance from the highest points of the five largest maximums to the line that is parallel to the centerline and does not intersect the profile; $h_{i \min }$ - distance from the lowest points of the five largest minimums to the same line; $R_{\text {max }}$ - greatest profile height; $y$-profile deviations from the line; $p$ - profile section level; $b_{i}$ - length of segments cut off at the given level $p$ (Bakumenko et al. 1997).

To determine the potential NPP pipe inner surface roughness value, specimens were fabricated from the pipe components cut out in the process of the pipe preventive maintenance (Demkin and Ryzhov 1981; Popov 1987).

The state of the pipe inner surface is influenced greatly by the erosive wear that changes its roughness in the process of operation. The mechanical impact on



Figure 1. Schematic representation of the surface microrelief. the inner surface differs depending on the pipe operation area. For instance, due to the surface curvature, the erosive wear in a bent section is greater than in a straight-line section. This may lead to a greater scatter of roughness data for pipelines with similar operating times. The obtained result for the maximum bottom surface roughness value can be therefore considered approximate. However, this is enough to estimate the maximum bottom surface roughness value for the test samples (Krautkremer and Krautkremer 1991; Kretov 1995; Scherbinsky 2005).

Five defective pipe segments of the $12 \mathrm{Kh} 18 \mathrm{~N} 10 \mathrm{~T}$ steel and five more segments of grade 20 steel, after different operating times, were used to determine experimentally the actual value of the pipe inner surface roughness. Besides, a piece of a new $\varnothing 273 \times 12$ pipe $(12 \mathrm{Kh} 18 \mathrm{~N} 10 \mathrm{~T}$ steel) and a piece of a new $\varnothing 159 \times 6$ pipe (grade 20 steel) were cut out. Both pieces were assigned respective test numbers shown in Table 1.

Table 1. Pipe segment roughness measurement results.

\begin{tabular}{lccc}
\hline \multirow{2}{*}{$\begin{array}{c}\text { Segment } \\
\text { No. }\end{array}$} & $\begin{array}{c}\text { Segment operating } \\
\text { time,days }\end{array}$ & \multicolumn{2}{c}{ Roughness $\mathbf{R}_{\mathbf{z}}, \boldsymbol{\mu m}$} \\
\cline { 3 - 4 } $\begin{array}{l}\text { 12Kh18N10T steel } \\
1\end{array}$ & 0 & $32.99 ; 33.20 ; 30.15$ & 32.11 \\
2 & 180 & $75.36 ; 73.83 ; 82.56$ & 77.52 \\
3 & 360 & $108.81 ; 137.00 ; 120.28$ & 122.03 \\
4 & 540 & $164.48 ; 172.20 ; 162.93$ & 166.53 \\
5 & 720 & $215.71 ; 219.05 ; 239.35$ & 224.70 \\
6 & 900 & $267.86 ; 214.08 ; 208.39$ & 230.11 \\
Grade 20 steel & & & \\
7 & 0 & $46.80 ; 44.93 ; 40.84$ & 44.19 \\
8 & 180 & $78.60 ; 76.20 ; 81.20$ & 78.67 \\
9 & 360 & $159.12 ; 144.16 ; 147.84$ & 150.37 \\
10 & 540 & $160.20 ; 167.10 ; 193.23$ & 173.51 \\
11 & 720 & $262.64 ; 235.81 ; 274.34$ & 257.60 \\
12 & 900 & $245.28 ; 263.21 ; 241.35$ & 249.95 \\
\hline
\end{tabular}

For illustration, Fig. 2 shows defective segments of an austenitic $12 \mathrm{Kh} 18 \mathrm{~N} 10 \mathrm{~T}$ steel pipe (Fig. 2a), cut out of a high-pressure reheater's piping, and defective segments of a perlite-class (grade 20 steel) pipe (Fig. 2b), cut out of a turbine plant's steam line.

The inner surface of each defective segment was cleaned and examined visually (GOST 2789-73 2019, GOST 5639-82 2019, GOST R ISO 4287-2014 2019). The surface roughness was measured on the worst-state surface of each segment using an Elcometer 7061 Marsurf PS1 roughness meter of the following performance: measurement range $R_{z}-350 / 180 / 90 \mu \mathrm{m}$; measurement accuracy - not more than $15 \%$. The measurement diagram is shown in Fig. 3.

Table 1 presents the pipe segment test numbers, operating times and inner (bottom) surface roughness measurement results for the three points for which the average roughness value was calculated (Saltykov 1976; Gulyaev 1986; Van Der Voort 1999; Muravyev et al. 2013).

Diagrams of the pipe segment bottom roughness dependence on operating time are presented in Fig. 4 (12Kh18N10T steel) and in Fig. 5 (grade 20 steel). 


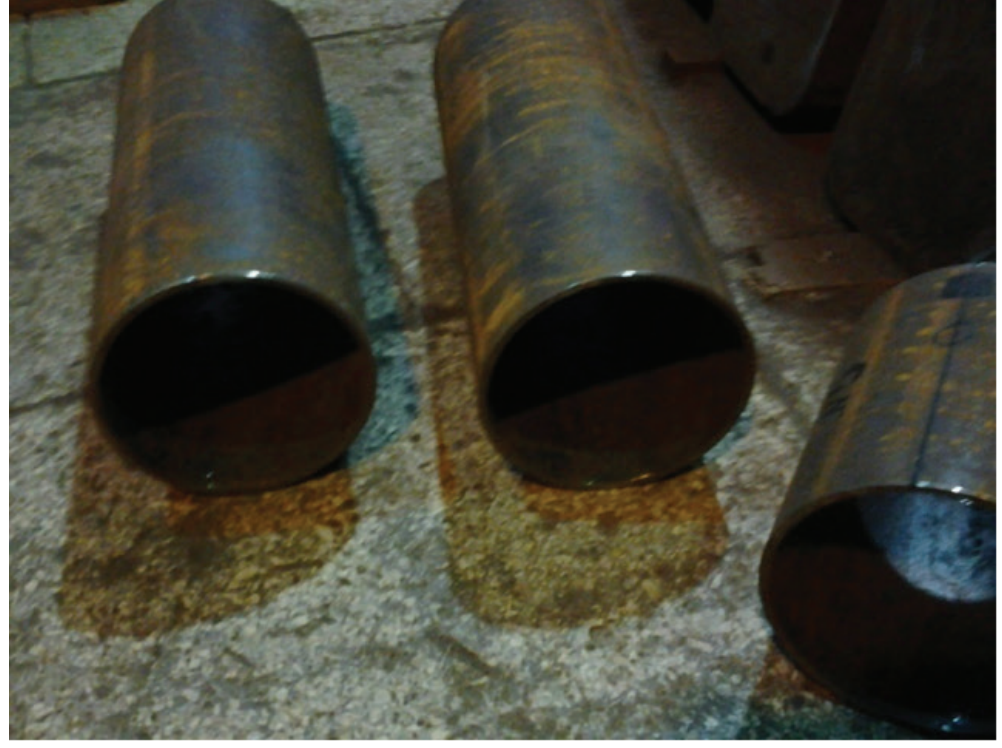

a.)

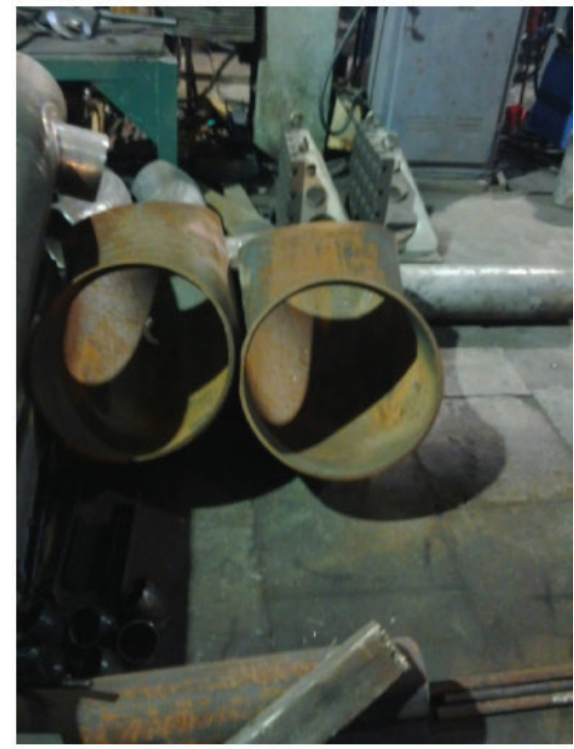

b.)

Figure 2. Defective pipe segments cut out of the NPP systems: a) 12Kh18N10T grade steel; b) grade 20 steel.

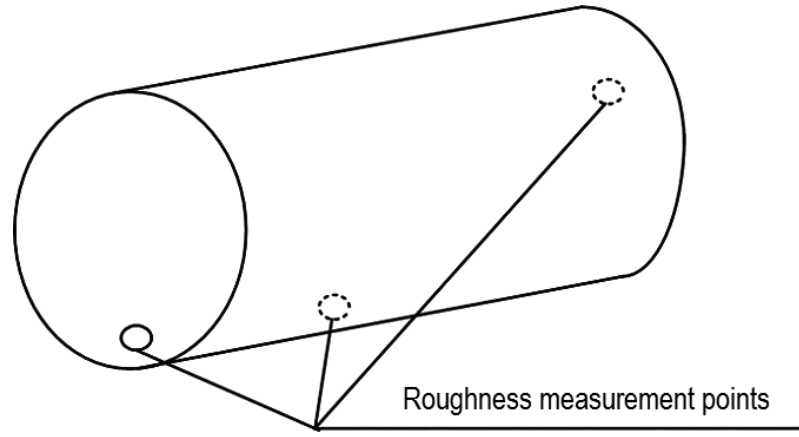

Figure 3. Pipe roughness measurement diagram.

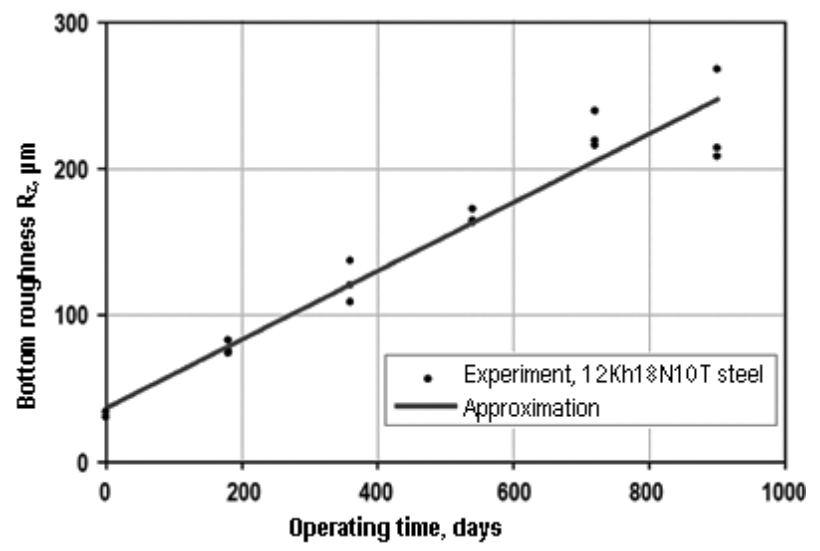

Figure 4. Bottom surface roughness of a high-pressure reheater's piping as a function of operating time.

Least square method was used for the linear dependence approximation with mathematical processing of data using the SigmaPlot code. The results obtained are as follows:



Figure 5. Turbine plant steam line bottom surface roughness as a function of operating time.

- $12 \mathrm{Kh} 18 \mathrm{~N} 10 \mathrm{~T}$ steel: $R_{z}=36.6+0.234 \times t ; R^{2}=0.97$,

- grade 20 steel: $R_{z}=45.6+0.252 \times t ; R^{2}=0.97$,

where $t$ is the operating time, days; and $R^{2}$ is the approximation confidence factor.

It has been obtained experimentally (see Table 1) that the maximum roughness $R_{z}$ is recorded at a level of $230 \mu \mathrm{m}$ for the $12 \mathrm{Kh} 18 \mathrm{~N} 10 \mathrm{~T}$ steel and at a level of $258 \mu \mathrm{m}$ for grade 20 steel. Three years were assumed to be the operating time for the systems since, as shown by observations, the pipe inner surface roughness $R_{z}$ changes insignificantly after this time.

The three-year prediction $(3 \times 365$ days $)$ for the obtained relations leads to the roughness value $R_{z}=293 \mu \mathrm{m}$ for the $12 \mathrm{Kh} 18 \mathrm{~N} 10 \mathrm{~T}$ steel and $R_{z}=321 \mu \mathrm{m}$ for grade 20 steel. The maximum roughness level on the specimen bottom surface is $R_{z}=313 \mu \mathrm{m}$ for the $12 \mathrm{Kh} 18 \mathrm{~N} 10 \mathrm{~T}$ steel and $R_{z}=337 \mu \mathrm{m}$ for grade 20 steel (see Table 1). Therefore, the specimens fabricated for the experiments to determine the dependence of the amplitude signal on the bottom sur- 
face roughness cover the three-year operating time of the NPP pipelines (Chernyavsky 1977; Anurev 2001).

\section{Conclusions}

The microrelief of the pipe inner surface changes in the process of the NPP pipeline operation leading to a change in the inner surface roughness parameter. The pipe inner surface roughness change is capable to distort substantially the ultrasonic grain size measurement data for the weld adjacent zone metal following the NPP pipe weld repair.
The maximum roughness $R_{z}$ obtained experimentally for the $12 \mathrm{Kh} 18 \mathrm{~N} 10 \mathrm{~T}$ steel is $230 \mu \mathrm{m}$ and that for grade 20 steel is $258 \mu \mathrm{m}$.

Dependences of the bottom surface roughness on the operating time of pipelines manufactured out of the $12 \mathrm{Kh} 18 \mathrm{~N} 10 \mathrm{~T}$ steel and grade 20 steel have been found.

Company specimens were fabricated for the ultrasonic inspection making it possible to take into account the attenuation of the signal from the pipe inner surface with different roughness values (Van Der Voort 1999; Trofimov and Globa 2012, 2014, 2015).

\section{References}

- Anurev VI (2001) Handbook for Designers - Mechanical Engineers. In 3 volumes, $8^{\text {th }}$ edn expanded. Mashinostroyeniye Publ, Moscow. [in Russian]

- Bakumenko VI, Bondarenko VA, Kosorukov SN, Atminis SA, Bersenev YuV, Vorontsov YuP, Komarov VI, Kudryavtsev AV, Lavrov LP, Mikhalev OR, Netsvetaev SA, Paveliev VI, Svalov GF, Svechnikov VB, Tinnikov ON, Finashin VN (1997) Quick Reference Book for Designers of Non-Standard Equipment. In 2 volumes (Vol. 1). Mashinostroyeniye Publ., Moscow, 544 pp. [in Russian]

- Chernyavsky KS (1977) Stereology in Metal Science. Metallurgiya Publ., Moscow, 208 pp. [in Russian]

- Demkin NB, Ryzhov EV (1981) Surface Quality and Contacts of Machine Parts. Mashinostroyeniye Publ., Moscow, 244 pp. [in Russian]

- GOST 2789-73 (2019) Surface Roughness. Parameters and Characteristics. https://internet-law.ru/gosts/gost/1419/ [accessed Apr 04, 2019] [in Russian]

- GOST 5639-82 (2019) Steels and Alloys. Methods for Detection and Determination of Grain Size. https://internet-law.ru/gosts/ gost/30103/ [accessed Apr 04, 2019] [in Russian]

- GOST R ISO 4287-2014 (2019) Geometric Characteristics of Products (GPS). Surface Structure. Profile Method. Terms, Definitions and Parameters of the Surface Structure. https://internet-law.ru/ gosts/gost/58916/ [accessed Apr 04, 2019]. [in Russian]

- Gulyaev AP (1986) Metal Science. Training book for universities ( $6^{\text {th }}$ edn.). Metallurgiya Publ., Moscow, 544 pp. [in Russian]
- Krautkremer Y, Krautkremer G (1991) Ultrasonic Inspection of Materials. Metallurgiya Publ., Moscow, 673 pp. [in Russian]

- Kretov YeF (1995) Ultrasonic Flaw Detection in Power Engineering. Radioavionika Publ., St. Petersburg, 317 pp. [in Russian]

- Muravyev VV, Muravyeva OV, Bayteryakov AV (2013) Method to determine the acoustic structural noise in metal. Intellektualnye Systemy V Proizvodstve 1: 143-148. [in Russian]

- Popov SA (1987) Grinding Operations - Training Book. Vysshaya Shkola Publ., Moscow, 383 pp. [in Russian]

- Saltykov SA (1976) Stereometric Metallography. Metallurgiya Publ., Moscow, 271 pp. [in Russian]

- Scherbinsky VG (2005) Technology of Ultrasonic Testing of Welded Joints. Tissot Publ., Moscow, 326 pp. [in Russian]

- Trofimov MA, Globa RA (2012) A technique for ultrasonic testing of the VK-50 reactor plant two-component metal. Izvestiya Vysshykh Uchebnykh Zavedeniy. Yadernaya Energetika 3: 1-32. [in Russian]

- Trofimov MA, Globa RA (2014) Measurement of the average grain size in a welded joint of the reactor plant feedwater pipeline. Tyazhyoloye Mashinostroyeniye 11-12: 28-31. [in Russian]

- Trofimov MA, Globa RA (2015) Investigation of the acoustic echo signal dependence on the average grain size in a welded joint. Eurasian Scientific Association 1(10(10)): 54-57. [in Russian]

- Van Der Voort GF (1999) Metallography: Principles and Practice. ASM International, $437 \mathrm{pp}$. 